\title{
PENILAIAN PROGRAM DIPLOMA TATA BUSANA TERHADAP PEMBENTUKAN SIKAP DAN PEMIKIRAN BERWIRAUSAHA ALUMNI
}

\author{
Ernawati $^{1}$, Nor Aishah Buang ${ }^{2}$ \\ ${ }^{1}$ Fakultas Pariwisata dan Perhotelan Universitas Negeri Padang \\ ${ }^{2}$ Fakultas Pendidikan Universitas Kebangsaan Malaysia \\ Email: ernafppunp@gmail.com, chahbuang@yahoo.com
}

\begin{abstract}
This study aims to assess the suitability of diploma programs on the formation of entrepreneurship attitudes and entrepreneurial thinking of the alumni of Fashion Program Faculty of Engineering, State University of Padang (TB FT UNP). This study uses an assessment model of input, prosess and product (CIPP) by Stufflebeam et al. 1971. Population in this research is alumni of FT UNP diploma program 218 people. All populations were sampled. Data analysis using descriptive statistics. The probability of the research instrument is measured by the correlation of the item value and the expert reference, whereas the trustworthiness index uses Cronbach Alpha value which shows the value between 0.70 to 0.97. The item's trustworthiness is high and acceptable. The result of research about curriculum, less suitable for the formation of entrepreneurship attitude with min score of 3.33 and skill level of 0.92 but according to the formation of entrepreneurial thinking with min score of 3.91 and skill level 0.91. The academic and infrastructural climate is less suitable for the formation of entrepreneurial attitude and thought of alumni with min score and expert skill respectively 3.49 and 0.83 and 3.47 and 0.46 . The process of teaching and learning is appropriate for the formation of entrepreneurship attitude with min score of 3.81 and skill level 0.76, but less suitable for the formation of entrepreneurship thinking with min score of 3.25 and skillful spell 0.74. The skill of the lecturer in guiding the implementation of industry training is appropriate to form the entrepreneurship attitude with min score of 3.88 and the skill of 0.78 but the skill is less suitable for the formation of entrepreneurial thinking with min score of 3.64 and the expert skill 0.79. The result of research about product dimension related to attitude and entrepreneurship stage of entrepreneurship of alumni as a whole is in high stage each with min score of 4.00 and skillful scholarship 039 and score min 3.90 and skillful spell 0.41 .
\end{abstract}

Keywords: assessment, attitude, thinking, entrepreneurship and alumni.

\section{PENDAHULUAN}

Indonesia sedang berada pada tahap perekonomian yang belum stabil karena ketahanan pada sektor tertentu yang masih lemah. Sektor tersebut adalah sektor yang berkaitan dengan wirausaha dan perniagaan. Oleh karena itu pemerintah Indonesia menjalankan beberapa kebijakan dalam bidang ekonomi untuk meningkatkan sektor wirausaha dan perniagaan. Firdaus (2012) mengemukakan bahwa terdapat empat masalah tenaga kerja di Indonesia. 
Masalah pertama ialah peluang kerja yang kurang. Masalah kedua ialah kualitas lulusan Pendidikan Tinggi (PT) masih rendah, yang mana hanya sejumlah $9,72 \%$ yang mendapat pekerjaan, ini karena keterampilan dan kebolehpasaran yang juga masih rendah. Masalah ketiga ialah jumlah pengangguran yang masih tinggi yaitu 19,99\% karena ketersediaan tenaga kerja yang tidak sejajar dengan keperluan industri. Masalah keempat ialah globalisasi dalam bidang barang dan jasa yang terkait erat dengan bidang tenaga kerja. Data tersebut menunjukkan bahwa sikap dan pemikiran berwirausaha lulusan harus sejajar dengan keperluan pasar kerja dan industri supaya daya serap pasaran lulusan tersebut meningkat.

Sebagai negara berkembang, Indonesia dituntut untuk bersaing dengan negara-negara maju yang menguasai perekonomian di dunia. Menurut David McClelland, untuk menjadi negara maju dan sejahtera, sekurangnya terdapat $2 \%$ wirausaha dari keseluruhan penduduk. Data kementerian Koperasi dan UKM pada tahun 2014 tentang jumlah wirausaha di beberapa negara, Indonesia hanya memiliki 1,65\% wirausaha dari 253,61 juta penduduk, Amerika Syerikat 12\%, Singapura 7,2 \%, Korea $4 \%$ dan Malaysia 2,1 \%. Dwi Aneka Jaya Kemasindo Witjaksono (Direktur Keuangan), menyatakan jumlah wirausaha Indonesia tersebut sangat memprihatinkan, untuk itu Indonesia harus melahirkan lebih banyak wirausaha-wirausaha muda.
Walau

bagaimanapun, pembudayaan wirausaha merupakan satu proses waktu yang panjang dan terus menerus yang melibatkan golongan siswa disekolah menengah, alumni Pendidikan Tinggi (PT) dan juga masyarakat (Ashmore 1990; Ronstadt 1990). Banyaknya pengangguran serta kurangnya minat berwirausaha menjadi autokritik terhadap peranan PT. Pihak pemerintah berharap agar PT menjalankan peranan yang besar dalam menciptakan alumni yang mempunyai pemikiran berwirausaha serta menanamkan sikap berwirausaha sehingga alumni tidak hanya pakar pada bidang akademik saja, namun juga berkemampuan menciptakan lapangan pekerjaan dan menjadi wirausaha yang bersedia menjadi wira ekonomi. Wirausaha muda harus diciptakan dan direncanakan dengan baik agar dapat mengurangi jumlah penganguran di Indonesia. Dapat disimpulkan bahwa seorang wirausaha merupakan orang yang agresif, inovatif untuk mempercepat pertumbuhan ekonomi. Coulter (2001) menjelaskan kepentingan wirausaha terdapat dalam tiga perkara iaitu inovasi, terwujutnya perniagaan baru dan peluang kerja. Menurut Fry (1993) wirausaha adalah menumbuhkan sesuatu organisasi perniagaan baru atau mengembangkan usaha yang ada secara inovatif.

Menurut Suryamin (kepala BPS), pengangguran pada Februari 2015 mencapai 7,4 juta orang, dengan tahap pengangguran terbuka (TPT) yang meningkat bagi lulusan pendidikan tinggi. Pada bulan Agustus 
2015, tercatat rincian jumlah pengangguran adalah sbb: lulusan Sekolah Menengah Kejuruan (SMK) sebanyak 12,65 \%. Lulusan Sekolah Menengah Atas sebanyak 10,32 \%. Sekolah Menengah Pertama dan Sekolah Dasar (SMP dan SD) masingmasing sebanyak $6,22 \%$ dan $2,74 \%$. Sarjana sebanyak $6,40 \%$, dan lulusan program diploma sebanyak 7,54\%. Data ini menunjukkan bahwa pengangguran lulusan program diploma mengalami peningkatan secara signifikan dari 5,87\% menjadi 7,54\%.

Beberapa pemerhati wirausaha di Indonesia dalam Siswoyo (2009) berpendapat bahwa sebahagian besar lulusan pendidikan tinggi lebih berstatus sebagai pencari kerja (job seeker) dari pada pencipta lapangan kerja (job creator). Sebab sistem pembelajaran yang diterapkan di berbagai perguruan tinggi di Indonesia umumnya terfokus kepada ketepatan waktu menamatkan pendidikan dan kepantasan dalam memperoleh pekerjaan, tanpa memberi perhatian terhadap kemampuan untuk menciptakan peluang kerja. Selanjutnya, Bob Sadino dalam Siswoyo (2009) menyatakan bahwa sistem pendidikan Indonesia kebanyakan masih menggunakan prinsip belajar untuk tahu, bukan belajar untuk melakukan sesuatu. Oleh sebab itu Ciputra (2008) menghimbau mahasiswa dari berbagai disiplin ilmu hendaknya jangan hanya diajarkan bagaimana dapat bekerja dengan baik, akan tetapi mesti diajarkan pula bagaimana untuk dapat menjadi pemilik perusahaan sesuai dengan latar belakang ilmu yang mereka miliki. Pendidikan wirausaha mesti dapat membekalkan mahasiswa dan alumni untuk mandiri dan bukan menjadi pencari kerja tetapi lebih kepada menciptakan lapangan pekerjaan.

Tujuan penelitian ini adalah untuk menilai kesesuai program diploma TB FT UNP bagi alumni dari tiga dimensi: (1) dimensi input, kesesuaian kurikulum, iklim akademik dan prasarana terhadap pembentukan sikap berwirausaha dan pemikiran berwirausaha bagi alumni TB FT UNP; (2) dimensi proses, mengenalpasti kesesuaian proses pengajaran dan pembelajaran serta keterampilan dosen dalam membimbing latihan industri terhadap pembentukan sikap dan pemikiran berwirausaha alumni TB FT UNP; (3) dimensi produk, mengenalpasti tahap sikap berwirausaha dan pemikiran berwirausaha alumni TB FT UNP.

Stufflebeam dan Shinkfield (1988) menyatakan bahwa penilaian merupakan satu semakan secara terus menerus terhadap pelaksanaan program. Pertama, tujuannya ialah untuk memberikan informasi kepada pihakpihak yang bertanggung jawab tentang sejauh mana aktivitas-aktivitas program itu dijalankan sesuai dengan yang direncanakan dan melaksanakan sesuai dengan keperluan berdasarkan sumbersumber yang sudah ada dengan cara yang sesuai. Tujuan kedua ialah memberi panduan untuk menyesuaikan atau melaksanakan perencanaan seperti mana yang diperlukan. Tujuan ketiga, 
adalah menilai dari waktu ke waktu sejauh mana peserta-peserta program menerima dan dapat menjalankan peranan mereka. Akhirnya, Stufflebeam dan Shinkfield (1988) pula menyatakan bahwa penilaian proses hendaklah memberikan rekod yang meluas terhadap program yang dijalankan, apakah pelaksanaan sesuai dengan yang diharapkan atau yang ditetapkan, dan juga bagaimana para pemerhati dan peserta mempertimbangkan kualitas program tersebut.

\section{METODE PENELITIAN}

Subjek dalam penelitian ini adalah alumni program diploma tata busana mulai tahun 2002 sampai tahun 2010 yang berjumlah 218 orang.

\section{Rancangan penelitian}

Penelitian yang dijalankan ini menggunakan reka bentuk kajian penilaian program yang diadaptasikan dari model CIPP (contexts, Input, Proses dan Produk) oleh Stufflebeam et al. (1971). Penilaian CIPP paling sesuai digunakan sebagai reka bentuk kajian penilaian program yang dijalankan dibandingkan dengan model-model penilaian lain. Selain itu model CIPP merupakan model yang komprehensif untuk memberi panduan dalam menjalankan kajian penilaian program (Stufflebeam et al. 2003).

\section{Populasi dan Sampel Penelitian}

Populasi dalam penelitian ini adalah alumni program diploma TB FT UNP, dari tahun 2002 hingga 2010 sebanyak 218 orang terdiri dari alumni yang bekerja di industri, alumni yang berwirausaha, alumni yang berbagai pekerjaan dan alumni yang belum bekerja. Semua anggota populasi digunakan sebagai responden penelitian. Menurut Sugiyono (2006), jika peneliti ingin hasil penelitiannya dengan kesalahan yang sangat kecil, sebaiknya semua populasi digunakan sebagai sampel.

\section{Prosedur penelitian}

Sebelum penelitian dijalankan maka dilakukan uji caba instrumen. Uji coba instrumen dilakukan untuk menguji kesahan dan kebolehpercayaan instrument penelitian yang digunakan, menguji kefahaman sampel, khususnya dari segi ketepatan, kesesuaian istilah, struktur kalimat dan penggunaan bahasa, serta menentukan waktu yang diperlukan untuk menjawab semua item - item pada instrumen dan juga urutan item. Uji coba instrumen dijalankan ke pada 35 orang alumni yang bukan merupakan responden dalam penelitian, tetapi mempunyai ciri-ciri yang hampir sama dengan responden penelitian. Mereka merupakan alumni tahun 2011. Semua set instrumen diterima kembali, namun peneliti hanya dapat merespon 30 set saja yaitu set yang telah diisi dengan lengkap untuk dianalisis dan membatalkan lima set intrumen yang didapati kurang lengkap. Ini sesuai dengan saran Sabitha dan Marican (2006) beliau mengemukakan kebanyakan pakar statistik setuju bahwa 30 orang adalah bilangan minimum yang diperlukan sebagai sampel untuk membolehkan satu penafsiran statistik yang bermakna dibuat.

Setelah menjalankan Uji coba instrumen, item-item yang lemah, kabur 
atau sukar difahami diperbaiki, disesuaikan dan dimurnikan untuk menambahbaikkan mutu instrumen penelitian. Kejelasan setiap pernyataan item adalah sangat penting dan dapat membantu responden menjawab dengan lebih berkesan (Rudzi Munap 2003). Pengumpulan data dilakukan dengan menggunakan kuesioner/angket setelah melalui uji validitas serta reliabilitas. Validitas instrumen penelitian diukur melalui korelasi nilai item dan rekomendasi pakar, sedangkan indeks kebolehpercayaan menggunakan nilai Cronbach Alpha yang menunjukkan nilai antara 0,70 hingga 0,97 . Kebolehpercayaan item adalah tinggi dan dapat diterima. Analisis data menggunakan statistik deskriptif. Menurut Mohd. Majid (2005), statistik deskriptif merupakan organisasi dan ringkasan data yang diperolehi dari hasil pemprosesan data. Hasilnya dapat ditampilkan berupa ilustrasi dalam bentuk tabel atau graf tentang data atau informasi.

Untuk mengukurimensi input dan kesesuaian proses pengajaran dan pembelajaran, keterampilan dosen dalam membimbing pelaksanaan industri dimensi proses. Digunakan analisis deskriptif dengan mengikut interpretasi pada Tabel 1.1 Skor min 1,00 hingga 2,33 menunjukkan tidak sesuai. Skor min 2,34 hingga 3,66 menunjukkan kurang sesuai, sedangkan skor min 3,67 hingga 5,00 adalah sesuai. Interpretasi ini berpedoman kepada interpretasi yang dibuat oleh jamil (2002). Walaupun beliau menggunakan interpretasi ini untuk menjawab permasalahan kajian mengenai budaya penelitian di sekolah, tetapi pada dasarnya interpretasi ini dapat juga digunakan untuk menjawab permasalahan dalam penelitian ini. Untuk mengukur sikap berwirausaha dan tahap pemikiran berwirausaha alumni pada dimensi produk, mengikut interpretasi pada table 1.2 yang diadaptasi dan disesuaikan dari interpretasi skor min yang dikemukakan oleh Jamil (2002). Skor min 1,00 hingga 2,33 menunjukkan kesannya pada tahap yang rendah. Skor min 2,34 hingga 3,66 menunjukkan kesannya pada tahap sederhana, sedangkan skor min 3,67 hingga 5,00 ini menunjukkan kesannya pada tahap yang tinggi.

Tabel 1 Interpretasi Skor Min Tahap Keberkesanan

Skor Min Interpretasi Skor Min

1.00 hingga 2.33 Tidak berkesan

2.34 hingga 3.66 Kurang berkesan

3.67 hingga $5.00 \quad$ Berkesan

Sumber: Jamil (2002)

Tabel 2 Interpretasi Skor Min Sikap Dan Tahap Pemikiran Berwirausaha

Skor Min Interpretasi Skor Min

\begin{tabular}{lc}
\hline 1.00 hingga 2.33 & Rendah \\
2.34 hingga 3.66 & Sederhana \\
3.67 hingga 5.00 & Tinggi \\
\hline
\end{tabular}

Sumber: Jamil (2002)

\section{HAS IL DAN PEMBAHASAN}

Berdasarkan hasil penelitian, maka dibuat pembahasan tentang variabel penilaian keberkesanan program diploma tata busana terhadap sikap berwirausaha dan pemikiran berwirausaha alumni sbb: 
1. Dimensi Input :

a. Kesesuaian Kurikulum Terhadap Pembentukan Sikap Berwirausaha dan Pemikiran Berwirausaha Usaha Alumni TB FT UNP.

Bahagian ini untuk menjawab dimensi input yaitu kesesuaian kurikulum terhadap pembentukan sikap berwirausaha dan pemikiran berwirausaha alumni TB FT UNP. Kurikulum terhadap pembentukan sikap berwirausaha secara keseluruhan adalah kurang sesuai dengan skor min 3.33 sisihan piawai 0.92. Dari 25 mata kuliah, 19 mata kuliah sesuai dan enam mata kuliah kurang sesuai terhadap pembentukan sikap berwirausaha, seperti pada tabel 3 .

Tabel 3. Skor Min Dan Sisihan Piawai Kesesuaian Kurikulum Terhadap Pembentukan Sikap Berwirausaha

\begin{tabular}{llrrr}
\hline No & Mata kuliah & \multicolumn{3}{c}{ Sikap berwirausaha } \\
& & Min & S.P & Interpretasi \\
\hline 1 & Manajemen Usaha Busana Konveksi & 4.45 & 0.66 & $\mathrm{~S}$ \\
2 & Manajemen Usaha Busana Butik & 4.40 & 0.74 & $\mathrm{~S}$ \\
3 & Desain Ragam Hias & 4.38 & 0.76 & $\mathrm{~S}$ \\
4 & Manajemn Usaha Busana Modeste/Tailor & 4.36 & 0.83 & $\mathrm{~S}$ \\
5 & Pengetahuan Tekstil 2 & 4.20 & 0.81 & $\mathrm{~S}$ \\
6 & Pelengkap busana & 4.20 & 0.79 & $\mathrm{~S}$ \\
7 & Pengetahuan busana & 4.19 & 0.81 & $\mathrm{~S}$ \\
8 & Pengetahuan Tekstil 1 & 4.16 & 0.81 & $\mathrm{~S}$ \\
9 & Teknologi busana & 4.13 & 0.84 & $\mathrm{~S}$ \\
10 & Seni Rupa dasar & 4.05 & 0.91 & $\mathrm{~S}$ \\
11 & Sulaman 1 & 3.90 & 0.84 & $\mathrm{~S}$ \\
12 & Metode Penyuluhan & 2.60 & 1.14 & $\mathrm{KS}$ \\
13 & KKM & 2.56 & 0.75 & $\mathrm{KS}$ \\
14 & Konstruksi Pola busana & 4.72 & 0.47 & $\mathrm{~S}$ \\
15 & Kerwirausahaan & 4.50 & 0.67 & $\mathrm{~S}$ \\
16 & Praktek Kerja & 4.39 & 0.72 & $\mathrm{~S}$ \\
17 & Busana Pria & 4.30 & 0.83 & $\mathrm{~S}$ \\
18 & Desain busana 1 & 4.28 & 0.71 & $\mathrm{~S}$ \\
19 & Desain busana 2 & 4.28 & 0.84 & $\mathrm{~S}$ \\
20 & Pengetahuan dan Teknik busana dasar & 4.28 & 0.91 & $\mathrm{~S}$ \\
21 & Pengantar Ekonomi & 4.12 & 0.91 & $\mathrm{~S}$ \\
22 & Tailoring & 2.94 & 1.16 & $\mathrm{KS}$ \\
23 & Lingeri & 2.81 & 0.95 & $\mathrm{KS}$ \\
24 & Grading & 2.75 & 1.03 & $\mathrm{KS}$ \\
25 & Metode Penelitian & 2.42 & 1.10 & $\mathrm{KS}$ \\
\hline Keseluruhan & 3.33 & 0.92 & $\mathrm{KS}$ \\
\hline & Nota: S.P=Sisihan Piawai S = Sesuai KS = Kurang Sesuai & TS = Tidak sesuai & & \\
& & & & \\
\end{tabular}

Kesesuaian kurikulum terhadap pembentukan pemikiran berwirausaha alumni secara keseluruhan adalah sesuai dengan skor min 3.91 dan sisihan piawai 0.91. Dari 25 mata kuliah, 19 mata kuliah sesuai dan enam mata kuliah kurang sesuai kepada pembentukan pemikiran berwirausaha. Mata kuliah tersebut seperti pada Tabel 4. 
Tabel 4. Skor Min Dan Sisihan Piawai Kesesuaian Kurikulum Terhadap Pemikiran Berwirausaha

\begin{tabular}{|c|c|c|c|c|}
\hline \multirow[t]{2}{*}{ No } & \multirow[t]{2}{*}{ Mata kuliah } & \multicolumn{3}{|c|}{ Pemikiran Berwirausaha } \\
\hline & & Min & S.P & Interpretasi \\
\hline 1 & MUB Konveksi & 4.44 & 0.72 & $\mathrm{~S}$ \\
\hline 2 & MUB Butik & 4.39 & 0.72 & $S$ \\
\hline 3 & Desain Ragam Hias & 4.42 & 0.76 & $S$ \\
\hline 4 & MUB Modeste/Tailor & 4.37 & 0.78 & $S$ \\
\hline 5 & Pengetahuan Tekstil 2 & 4.19 & 0.77 & $S$ \\
\hline 6 & Pelengkap busana & 4.20 & 0.77 & $S$ \\
\hline 7 & Pengetahuan busana & 4.27 & 0.72 & $S$ \\
\hline 8 & Pengetahuan Tekstil 1 & 4.17 & 0.77 & $S$ \\
\hline 9 & Teknologi busana & 4.14 & 0.87 & $S$ \\
\hline 10 & Seni Rupa dasar & 4.08 & 0.89 & $S$ \\
\hline 11 & Sulaman 1 & 3.92 & 0.79 & $\mathrm{~S}$ \\
\hline 12 & Metode Penyuluhan & 2.63 & 1.18 & $\mathrm{KS}$ \\
\hline 13 & KKM & 2.56 & 0.77 & KS \\
\hline 14 & Konstruksi Pola busana & 4.79 & 0.40 & S \\
\hline 15 & Kerwirausahaan & 4.55 & 0.62 & $S$ \\
\hline 16 & Praktek Kerja & 4.41 & 0.72 & $S$ \\
\hline 17 & Busana Pria & 4.38 & 0.72 & $S$ \\
\hline 18 & Desain busana 1 & 4.13 & 0.71 & $S$ \\
\hline 19 & Desain busana 2 & 4.31 & 0.78 & $S$ \\
\hline 20 & Pengetahuan dan Teknik busana dasar & 4.33 & 0.85 & $S$ \\
\hline 21 & Pengantar Ekonomi & 4.22 & 0.85 & S \\
\hline 22 & Tailoring & 3.09 & 1.14 & $\mathrm{KS}$ \\
\hline 23 & Lingeri & 2.71 & 1.01 & $\mathrm{KS}$ \\
\hline 24 & Grading & 2.68 & 1.00 & $\mathrm{KS}$ \\
\hline 25 & Metode Penelitian & 2.41 & 1.13 & $\mathrm{KS}$ \\
\hline \multicolumn{2}{|c|}{ Keseluruhan } & 3.91 & 0.91 & $\mathrm{~S}$ \\
\hline
\end{tabular}

Bahagian ini untuk menjawab dimensi input berkaitan dengan kesesuaian iklim akademik dan prasarana yang disediakan jurusan untuk pelaksanaan program diploma terhadap pembentukan sikap dan pemikiran berwirausaha alumni TB FT UNP.
Iklim akademik dan prasarana terhadap pembentukan sikap berwirausaha alumni secara keseluruhan adalah kurang sesuai, skor min 3,49 dan sisihan piawai 0,83. Dari empat belas item, semua item kurang sesuai terhadap pembentukan sikap berwirausaha, seperti pada Tabel 5 


\section{Tabel 5 Skor Min Dan Sisihan Piawai Kesesuaian Iklim Akademik Dan} Prasarana Terhadap Pembentukan Sikap Berwirausaha

\begin{tabular}{|c|c|c|c|c|}
\hline \multirow[t]{2}{*}{ No } & \multirow[t]{2}{*}{ Item } & \multicolumn{3}{|c|}{ Sikap berwirausaha } \\
\hline & & Min & S.P & Interpretasi \\
\hline 1 & $\begin{array}{l}\text { Jurusan menyediakan tempat latihan berwirausaha yang } \\
\text { bersih dan asri }\end{array}$ & 3.44 & 0.79 & $\mathrm{KS}$ \\
\hline 2 & $\begin{array}{l}\text { Jurusan menyediakan tempat yang strategis untuk latihan } \\
\text { berwirausaha }\end{array}$ & 3.04 & 0.86 & $\mathrm{KS}$ \\
\hline 3 & Terjalinnya komunikasi antara dosen dengan mahasiswa & 3.03 & 0.84 & $\mathrm{KS}$ \\
\hline 4 & Lingkungan kampus yang bersih membuat saya nyaman & 3.19 & 0.80 & $\mathrm{KS}$ \\
\hline 5 & Aturan yang jelas dalam menjalankan aktivitas di kampus & 3.33 & 0.78 & $\mathrm{KS}$ \\
\hline 6 & Lingkungan kampus yang asri dan tertata dengan baik & 3.44 & 0.79 & $\mathrm{KS}$ \\
\hline 7 & $\begin{array}{l}\text { Jurusan menyediakan ruang kuliah yang sesuai dengan } \\
\text { keperluan mahasiswa }\end{array}$ & 3.52 & 0.88 & $\mathrm{KS}$ \\
\hline 8 & Jurusan menyediakan buku yang sesuai keperluan & 3.50 & 0.89 & $\mathrm{KS}$ \\
\hline 9 & $\begin{array}{l}\text { Jurusan menyediakan ruang baca yang sesuai dengan } \\
\text { keperluan mahasiswa }\end{array}$ & 3.57 & 0.90 & $\mathrm{KS}$ \\
\hline 10 & $\begin{array}{l}\text { Jurusan menyediakan alat yang diperlukan untuk latihan } \\
\text { berwirausaha }\end{array}$ & 3.25 & 0.88 & $\mathrm{KS}$ \\
\hline 11 & $\begin{array}{l}\text { Jurusan menyediakan bahan yang diperlukan mahasiswa } \\
\text { untuk latihan berwirausaha }\end{array}$ & 3.10 & 0.97 & KS \\
\hline 12 & Jurusan menyediakan bahan bantu pembelajaran & 3.57 & 0.81 & $\mathrm{KS}$ \\
\hline 13 & Perlengkapan pada ruang kuliah sesuai dengan keperluan & 3.65 & 0.86 & $\mathrm{KS}$ \\
\hline 14 & Alat-alat untuk praktik busana tersedia & 3.31 & 0.83 & $\mathrm{KS}$ \\
\hline & Keseluruhan & 3.49 & 0.83 & $\mathrm{KS}$ \\
\hline
\end{tabular}

Tabel 6 menunjukkan kesesuaian iklim akademik dan prasarana terhadap pemikiran berwirausaha alumni secara keseluruhan kurang sesuai, dengan skor min 3,47 dan sisihan piawai 0,46 . Dari empat belas item hanya tiga item yang sesuai sedangkan 11 item kurang sesuai terhadap pembentukan pemikiran berwirausaha. 


\section{Tabel 6 Skor Min Dan Sisihan Piawai Tahap Kesesuaian Iklim Akademik} Dan Prasarana Terhadap Pementukan Pemikiran Berwirausaha

\begin{tabular}{|c|c|c|c|c|}
\hline \multirow[t]{3}{*}{ No } & \multirow{3}{*}{ Berwirausah } & \\
\hline & & Berwirausaha & \multicolumn{2}{|c|}{ Pemikiran } \\
\hline & & Min & S.P & Interpretasi \\
\hline 1 & $\begin{array}{l}\text { Jurusan menyediakan tempat latihan berwirausaha yang } \\
\text { bersih dan asri }\end{array}$ & 3.58 & 0.80 & $\mathrm{KS}$ \\
\hline 2 & $\begin{array}{l}\text { Jurusan menyediakan tempat yang strategis untuk latihan } \\
\text { berwirausaha }\end{array}$ & 3.48 & 0.83 & $\mathrm{KS}$ \\
\hline 3 & Terjalinnya komunikasi antara dosen dengan mahasiswa & 3.13 & 0.81 & KS \\
\hline 4 & Lingkungan kampus yang bersih membuat saya nyaman & 3.16 & 0.92 & $\mathrm{KS}$ \\
\hline 5 & Aturan yang jelas dalam menjalankan aktivitas di kampus & 3.43 & 0.74 & $\mathrm{KS}$ \\
\hline 6 & Lingkungan kampus yang asri dan tertata dengan baik & 3.46 & 0.75 & $\mathrm{KS}$ \\
\hline 7 & $\begin{array}{l}\text { Jurusan menyediakan ruang kuliah yang sesuai dengan } \\
\text { keperluan mahasiswa }\end{array}$ & 3.56 & 0.79 & $\mathrm{KS}$ \\
\hline 8 & Jurusan menyediakan buku yang sesuai dengan keperluan & 3.55 & 0.81 & KS \\
\hline 9 & $\begin{array}{l}\text { Jurusan menyediakan ruang baca yang sesuai dengan } \\
\text { keperluan mahasiswa }\end{array}$ & 3.63 & 0.83 & $\mathrm{KS}$ \\
\hline 10 & $\begin{array}{l}\text { Jurusan menyediakan alat yang diperlukan untuk latihan } \\
\text { berwirausaha }\end{array}$ & 3.32 & 0.86 & $\mathrm{KS}$ \\
\hline 11 & $\begin{array}{l}\text { Jurusan menyediakan bahan yang diperlukan mahasiswa } \\
\text { untuk latihan berwirausaha }\end{array}$ & 3.21 & 0.86 & $\mathrm{KS}$ \\
\hline 12 & Jurusan menyediakan bahan bantu pembelajaran & 3.69 & 0.74 & S \\
\hline 13 & Perlengkapan pada ruang kuliah sesuai dengan keperluan & 3.72 & 0.83 & S \\
\hline 14 & Alat-alat untuk praktik busana tersedia & 3.79 & 0.67 & $\mathrm{~S}$ \\
\hline & Keseluruhan & 3.47 & 0.46 & $\mathrm{KS}$ \\
\hline
\end{tabular}

2. Dimensi Proses

a. Kesesuaian Proses Pengajaran dan Pembelajaran Terhadap Pembentukan Sikap berwirausaha dan pemikiran berwirausaha alumni TB FT UNP.

Bahagian ini ditujukan untuk menjawab dimensi proses berkaitan dengan pelaksanaan program yaitu kesesuaian proses pengajaran dan pembelajaran terhadap pembentukan sikap berwirausaha dan pemikiran berwirausaha alumni TB FT UNP. Proses pengajaran dan pembelajaran terhadap pembentukan sikap berwirausaha secara keseluruhan kurang sesuai dengan skor min adalah 3,26 dan sisihan piawai adalah 0,76. Dari 24 item, dua item kurang sesuai terhadap pembentukan sikap berwirausaha, seperti tabel 7 . 


\section{Tabel 7. Skor Min Dan Sisihan Piawai Kesesuaian Proses Pengajaran Dan Pembelajaran Terhadap Pembentukan Sikap Berwirausaha}

\begin{tabular}{|c|c|c|c|c|}
\hline \multirow[t]{2}{*}{ No } & \multirow[t]{2}{*}{ Item } & \multicolumn{3}{|c|}{ Sikap berwirausaha } \\
\hline & & Min & S.P & Interpretasi \\
\hline 1 & Pembelajaran kewirausahaan adalah sangat bermanfaat & 4.04 & 0.77 & $\mathrm{~S}$ \\
\hline 2 & $\begin{array}{l}\text { Mata kuliah kewirausahaan yang ditawarkan dapat menjadikan } \\
\text { mahasiswa sebagai seorang wirausaha }\end{array}$ & 3.73 & 0.76 & $S$ \\
\hline 3 & Dosen melaksanakan pembelajaran mengikut silabus & 3.93 & 0.68 & $S$ \\
\hline 4 & Pembelajaran kewirausahaan memiliki aturan yang jelas & 3.71 & 0.75 & S \\
\hline 5 & $\begin{array}{l}\text { Pembelajaran kewirausahaan membuat saya dapat menciptakan } \\
\text { produk untuk generasi yang akan datang }\end{array}$ & 3.91 & 0.70 & $\mathrm{~S}$ \\
\hline 6 & $\begin{array}{l}\text { Pembelajaran kewirausahan dalam bidang busana menjadikan saya } \\
\text { lebih bertanggung jawab }\end{array}$ & 3.85 & 0.80 & $\mathrm{~S}$ \\
\hline 7 & $\begin{array}{l}\text { Pembelajaran kewirausahaan membuat saya lebih percaya diri dalam } \\
\text { membuat keputusan }\end{array}$ & 4.02 & 0.70 & $\mathrm{~S}$ \\
\hline 8 & $\begin{array}{l}\text { Dosen sering mengaitkan pembelajaran dengan isu-isu kewirausahaan } \\
\text { terkini atau terbaru }\end{array}$ & 3.68 & 0.77 & $\mathrm{~S}$ \\
\hline 9 & $\begin{array}{l}\text { Dosen berusaha menimbulkan minat saya untuk membuka usaha } \\
\text { dibidang busana }\end{array}$ & 3.74 & 0.77 & $\mathrm{~S}$ \\
\hline 10 & $\begin{array}{l}\text { Dosen menyajikan materi yang sesuai dan membuka wawasan } \\
\text { mahasiswa untuk menjadi usahawan }\end{array}$ & 3.86 & 0.71 & $\mathrm{~S}$ \\
\hline 11 & $\begin{array}{l}\text { Dosen menggunakan materi pengajaran dan pembelajaran yang } \\
\text { diperoleh dari berbagai sumber }\end{array}$ & 3.80 & 0.81 & $\mathrm{~S}$ \\
\hline 12 & $\begin{array}{l}\text { Dosen membimbing saya ketika menjalankan praktik kewirausahaan } \\
\text { bidang busana }\end{array}$ & 3.90 & 0.66 & $\mathrm{~S}$ \\
\hline 13 & Dalam proses pembelajaran sering menggunakan media gambar & 3.48 & 0.77 & $\mathrm{KS}$ \\
\hline 14 & $\begin{array}{l}\text { Pembelajaran kewirausahaan sangat membantu saya dalam } \\
\text { menghasilkan produk yang sesuai dengan selera masyarakat }\end{array}$ & 3.96 & 0.73 & $\mathrm{~S}$ \\
\hline 15 & $\begin{array}{l}\text { Komputer disediakan untuk memudahkan dosen melaksanakan } \\
\text { pembelajaran kewirausahaan }\end{array}$ & 3.66 & 0.84 & $\mathrm{~S}$ \\
\hline 16 & $\begin{array}{l}\text { Aktivitas pembelajaran berpedoman kepada kurikulum yang } \\
\text { disediakan prodi dan jurusan }\end{array}$ & 3.90 & 0.70 & $\mathrm{~S}$ \\
\hline 17 & Saya dapat mengenalpasti ide-ide yang berpotensi & 3.72 & 0.75 & S \\
\hline 18 & Saya dapat menjangka pasaran baru & 3.72 & 0.70 & S \\
\hline 19 & $\begin{array}{l}\text { Saya dapat mengaitkan keinginan masyarakat dengan idea untuk } \\
\text { membaiki produk yang lebih baik }\end{array}$ & 3.77 & 0.81 & $\mathrm{~S}$ \\
\hline 20 & $\begin{array}{l}\text { Saya memiliki keterampilan dalam memilih bidang usaha yang } \\
\text { diperlukan masyarakat }\end{array}$ & 3.71 & 0.91 & $\mathrm{~S}$ \\
\hline 21 & Saya yakin berhasil berusaha dalam bidang busana & 3.79 & 0.76 & S \\
\hline 22 & $\begin{array}{l}\text { Proses pembelajaran membuat saya lebih yakin untuk membuka suatu } \\
\text { usaha }\end{array}$ & 3.77 & 0.86 & S \\
\hline 23 & Saya memiliki keterampilan membuat rencana usaha & 3.82 & 0.77 & S \\
\hline 24 & Pembelajaran kewirausahaan dalam bidang busana menjadikan saya & & & \\
\hline & lebih mudah menemukan peluang usaha & 3.61 & 0.75 & $\mathrm{KS}$ \\
\hline & seluruhan & 3.26 & 0.76 & $\mathrm{KS}$ \\
\hline
\end{tabular}

Nota: $\quad$ S.P = Sisihan Piawai $\quad$ S = Sesuai $\quad K S=$ Kurang Sesuai $\quad$ TS = Tidak Sesuai.

b. Kesesuaian proses pengajaran dan pembelajaran terhadap pembentukan pemikiran berwirausaha alumni secara keseluruhan adalah kurang sesuai dengan skor min adalah 3.25 dan sisihan piawai adalah 0.74. Dari 24 item, hanya dua item yang sesuai dan 22 item kurang sesuai terhadap pembentukan pemikiran berwirausaha, seperti Tabel 8 
Tabel 8 Skor Min Dan Sisihan Piawai Tahap Kesesuaian Proses Pengajaran Dan Pembelajaran Terhadap Pembentukan Pemikiran Berwirausaha

\begin{tabular}{|c|c|c|c|c|}
\hline \multirow[b]{2}{*}{ No } & \multirow[b]{2}{*}{ Item } & \multicolumn{3}{|c|}{ Pemikiran Berwirausaha } \\
\hline & & Min & S.P & Interpretasi \\
\hline 1 & Pembelajaran kewirausahaan sangat bermanfaat & 3.17 & 0.98 & KS \\
\hline 2 & $\begin{array}{l}\text { Mata kuliah kewirausahaan yang ditawarkan dapat menjadikan } \\
\text { mahasiswa sebagai seorang wirausaha }\end{array}$ & 3.15 & 0.63 & KS \\
\hline 3 & Dosen melaksanakan pembelajaran mengikut silabus & 3.68 & 0.65 & S \\
\hline 4 & Pembelajaran kewirausahaan memiliki aturan yang jelas & 3.44 & 0.70 & $\mathrm{KS}$ \\
\hline 5 & $\begin{array}{l}\text { Pembelajaran kewirausahaan membuat saya dapat menciptakan } \\
\text { produk untuk generasi yang akan datang }\end{array}$ & 3.34 & 0.65 & KS \\
\hline 6 & $\begin{array}{l}\text { Pembelajaran kewirausahaan dalam bidang busana menjadikan saya } \\
\text { lebih bertanggung jawab }\end{array}$ & 4.18 & 0.79 & $\mathrm{KS}$ \\
\hline 7 & $\begin{array}{l}\text { Pembelajaran kewirausahaan membuat saya lebih percaya diri dalam } \\
\text { membuat keputusan }\end{array}$ & 4.48 & 0.67 & $\mathrm{KS}$ \\
\hline 8 & $\begin{array}{l}\text { Dosen sering mengaitkan pembelajaran dengan isu-isu } \\
\text { kewirausahaan terkini atau terbaru }\end{array}$ & 3.12 & 0.65 & $\mathrm{KS}$ \\
\hline 9 & $\begin{array}{l}\text { Dosen berusaha menimbulkan minat saya untuk membuka usaha } \\
\text { dibidang busana }\end{array}$ & 2.98 & 0.90 & $\mathrm{KS}$ \\
\hline 10 & $\begin{array}{l}\text { Dosen menyajikan materi yang sesuai dan membuka wawasan } \\
\text { mahasiswa untuk menjadi usahawan }\end{array}$ & 3.16 & 0.66 & $\mathrm{KS}$ \\
\hline 11 & $\begin{array}{l}\text { Dosen menggunakan materi pengajaran dan pembelajaran yang } \\
\text { diperoleh dari berbagai sumber }\end{array}$ & 3.31 & 0.79 & $\mathrm{KS}$ \\
\hline 12 & $\begin{array}{l}\text { Dosen membimbing saya ketika menjalankan praktik berwirausaha } \\
\text { bidang busana }\end{array}$ & 3.05 & 0.90 & $\mathrm{KS}$ \\
\hline 13 & Proses pembelajaran sering mengunakan media gambar & 2.87 & 0.73 & KS \\
\hline 14 & $\begin{array}{l}\text { Pembelajaran kewirausahaan sangat membantu saya dalam } \\
\text { menghasilkan produk yang sesuai dengan selera masyarakat }\end{array}$ & 3.37 & 0.65 & KS \\
\hline 15 & $\begin{array}{l}\text { Komputer disediakan untuk memudahkan dosen melaksanakan } \\
\text { pembelajaran kewirausahaan }\end{array}$ & 2.85 & 0.87 & KS \\
\hline 16 & $\begin{array}{l}\text { Aktivitas pembelajaran berpedoman kepada kurikulum yang } \\
\text { disediakan prodi dan jurusan }\end{array}$ & 3.75 & 0.70 & $\mathrm{~S}$ \\
\hline 17 & Saya dapat mengenalpasti ide-ide yang berpotensi & 3.36 & 0.62 & KS \\
\hline 18 & Saya dapat memperkirakan pasaran baru & 3.27 & 0.58 & KS \\
\hline 19 & $\begin{array}{l}\text { Saya dapat mengaitkan keinginan masyarakat dengan memperbaiki } \\
\text { produk ke hasil yang lebih baik }\end{array}$ & 3.23 & 0.62 & KS \\
\hline 20 & $\begin{array}{l}\text { Saya memiliki keterampilan dalam memilih bidang usaha yang } \\
\text { diperlukan masyarakat }\end{array}$ & 2.94 & 0.81 & KS \\
\hline 21 & Saya yakin berhasil berusaha dalam bidang busana & 3.26 & 0.68 & KS \\
\hline 22 & $\begin{array}{l}\text { Proses pembelajaran membuat saya lebih yakin untuk membuka } \\
\text { suatu usaha }\end{array}$ & 3.37 & 0.75 & KS \\
\hline 23 & Saya memiliki keterampilan membuat rencana usaha & 3.37 & 0.67 & KS \\
\hline 24 & $\begin{array}{l}\text { Pembelajaran kewirausahaan menjadikan saya lebih mudah } \\
\text { menemukan peluang usaha }\end{array}$ & 2.42 & 0.63 & $\mathrm{KS}$ \\
\hline Kes & uruhan & 3.25 & 0.74 & KS \\
\hline
\end{tabular}

c. Kesesuaian Keterampilan Dosen Dalam Membimbing Pelaksanaan Latihan Industri Terhadap Pembentukan Sikap berwirausaha dan Pemikiran Berwirausaha Alumni TB FT UNP.
Bahagian ini ditujukan untuk menjawab permasalahan dimensi proses pelaksanaan program yaitu keterampilan dosen dalam membimbing pelaksanaan latihan industri terhadap pembentukan sikap berwirausaha dan 
pemikiran berwirausaha bagi alumni TB FT UNP. Keterampilan dosen dalam membimbing pelaksanaan latihan industri terhadap pembentukan sikap berwirausaha secara keseluruhan adalah sesuai, dengan skor min 3,88 dan sisihan piawai 0,78 . Dari 13 item hanya
9 yang sesuai terhadap pembentukan sikap berwirausaha, satu item tidak sesuai dan tiga item kurang sesuai terhadap pembentukan sikap berwirausaha alumni, seperti tabel 9 .

\begin{tabular}{|c|c|c|c|c|}
\hline \multirow{2}{*}{ No } & \multirow{2}{*}{ Item } & \multicolumn{3}{|c|}{ Sikap berwirausaha } \\
\hline & & Min & S.P & Interpretasi \\
\hline 1 & $\begin{array}{l}\text { Dosen membimbing saya secara kooperatif ketika latihan } \\
\text { industri }\end{array}$ & 3.71 & 0.65 & $\mathrm{~S}$ \\
\hline 2 & $\begin{array}{l}\text { Dosen mampu mengenal pasti masalah-masalah yang saya } \\
\text { hadapi selama menjalankan latihan industri }\end{array}$ & 3.75 & 0.74 & S \\
\hline 3 & $\begin{array}{l}\text { Dosen selalu memberi dukungan moral kepada saya dalam } \\
\text { melaksanakan latihan industri }\end{array}$ & 2.57 & 0.54 & $\mathrm{KS}$ \\
\hline 4 & $\begin{array}{l}\text { Dosen menunjukkan fikiran positif terhadap saya selama } \\
\text { menjalankan latihan industri }\end{array}$ & 2.82 & 0.99 & $\mathrm{KS}$ \\
\hline 5 & Dosen membimbing latihan industri secara hand-on & 3.68 & 0.83 & $\mathrm{~S}$ \\
\hline 6 & $\begin{array}{l}\text { Dosen selalu memberi penyelesaian masalah yang dihadapi } \\
\text { dalam melaksanakan latihan industri }\end{array}$ & 3.75 & 0.62 & S \\
\hline 7 & $\begin{array}{l}\text { Dosen pembimbing selalu berdiskusi berkaitan aktivitas latihan } \\
\text { industry }\end{array}$ & 2.04 & 0.59 & $\mathrm{TS}$ \\
\hline 8 & $\begin{array}{l}\text { Dosen pembimbing selalu memberi dukungan dalam mengenal } \\
\text { pasti aktivitasi-aktivitas yang dapat dijalankan di industri }\end{array}$ & 3.78 & 0.77 & $\mathrm{~S}$ \\
\hline 9 & $\begin{array}{l}\text { Pengalaman dosen terhadap industri membantu saya mengenal } \\
\text { peluang usaha yang relevan dengan ilmu yang saya pelajari. }\end{array}$ & 3.92 & 0.65 & S \\
\hline 10 & $\begin{array}{l}\text { Dosen pembimbing memiliki hubungan yang baik dengan } \\
\text { pimpinan industri }\end{array}$ & 2.83 & 0.60 & KS \\
\hline 11 & $\begin{array}{l}\text { Dosen pembimbing berbagi pengalaman dengan pimpinan } \\
\text { indusri dalam membimbing saya ketika melaksanakan latihan } \\
\text { industry }\end{array}$ & 3.72 & 0.80 & S \\
\hline 12 & $\begin{array}{l}\text { Dosen pembimbing mampu mendorong pimpinan industri } \\
\text { memberi motivasi saya dalam melaksanakan latihan industri }\end{array}$ & 3.77 & 0.72 & $\mathrm{~S}$ \\
\hline 13 & $\begin{array}{l}\text { Dosen pembimbing dan pimpinan industri sering memberikan } \\
\text { contoh-contoh jenis usaha yang sesuai dengan bidang busana }\end{array}$ & 3.78 & 0.81 & $\mathrm{~S}$ \\
\hline \multicolumn{2}{|r|}{$\begin{array}{l}\text { Keseluruhan } \\
\text { Soto }\end{array}$} & 3.88 & 0.78 & $\mathrm{~S}$ \\
\hline
\end{tabular}

Nota: $\mathrm{S} . \mathrm{P}=$ Sisihan Piawai $\quad \mathrm{S}=$ Sesuai $\quad \mathrm{KS}=$ Kurang Sesuai $\quad \mathrm{TS}=$ Tidak Sesuai

Keterampilan dosen dalam membimbing pelaksanaan latihan industri terhadap pembentukan pemikiran berwirausaha secara keseluruhan kurang sesuai dengan skor min 3,64 dan sisihan piawai 0,79. Dari 13 item, satu item tidak sesuai dengan skor min 2.07 dan sisihan piawai 0.47 , seperti tabel 10. 
Tabel 10 Skor Min Dan Sisihan Piawai Kesesuaian Keterampilan Dosen Dalam Membimbing Pelaksanaan Latihan Industri Terhadap Pemikiran Berwirausaha

\begin{tabular}{|c|c|c|c|c|}
\hline \multirow[t]{2}{*}{ No } & \multirow[t]{2}{*}{ Item } & \multicolumn{3}{|c|}{ Pemikiran Berwirausaha } \\
\hline & & Min & SP & Interpretasi \\
\hline 1 & $\begin{array}{l}\text { Dosen membimbing saya secara kooperatif ketika latihan } \\
\text { industri }\end{array}$ & 3.74 & 0.72 & $\mathrm{~S}$ \\
\hline 2 & $\begin{array}{l}\text { Dosen mampu mengenal pasti masalah-masalah yang saya } \\
\text { hadapi selama menjalankan latihan industri }\end{array}$ & 3.74 & 0.77 & $\mathrm{~S}$ \\
\hline 3 & $\begin{array}{l}\text { Dosen selalu memberi dukungan moral kepada saya dalam } \\
\text { melaksanakan latihan industri }\end{array}$ & 3.80 & 0.66 & $S$ \\
\hline 4 & $\begin{array}{l}\text { Dosen menunjukkan fikiran positif terhadap saya selama } \\
\text { menjalankan latihan industri }\end{array}$ & 3.89 & 0.42 & $\mathrm{~S}$ \\
\hline 5 & Dosen membimbing latihan industri secara hand-on & 3.75 & 0.73 & $\mathrm{~S}$ \\
\hline 6 & $\begin{array}{l}\text { Dosen selalu memberi penyelesaian masalah yang dihadapi } \\
\text { dalam melaksanakan latihan industri }\end{array}$ & 3.70 & 0.66 & S \\
\hline 7 & $\begin{array}{l}\text { Dosen pembimbing selalu berdiskusi berkaitan aktivitas } \\
\text { latihan industry }\end{array}$ & 3.76 & 0.85 & $S$ \\
\hline 8 & $\begin{array}{l}\text { Dosen pembimbing selalu memberi dukungan dalam } \\
\text { mengenal pasti aktivitasi-aktivitas yang dapat dijalankan di } \\
\text { industri }\end{array}$ & 2.07 & 0.47 & TS \\
\hline 9 & $\begin{array}{l}\text { Pengalaman dosen terhadap industri membantu saya } \\
\text { mengenal peluang usaha yang relevan dengan ilmu yang saya } \\
\text { pelajari. }\end{array}$ & 3.93 & 0.71 & $\mathrm{~S}$ \\
\hline 10 & $\begin{array}{l}\text { Dosen pembimbing memiliki hubungan yang baik dengan } \\
\text { pimpinan industri }\end{array}$ & 3.73 & 0.66 & $\mathrm{~S}$ \\
\hline 11 & $\begin{array}{l}\text { Dosen pembimbing berbagi pengalaman dengan pimpinan } \\
\text { indusri dalam membimbing saya ketika melaksanakan latihan } \\
\text { industri }\end{array}$ & 3.76 & 0.79 & $\mathrm{~S}$ \\
\hline 12 & $\begin{array}{l}\text { Dosen pembimbing mampu mendorong pimpinan industri } \\
\text { memberi motivasi saya dalam melaksanakan latihan industri }\end{array}$ & 3.75 & 0.76 & $\mathrm{~S}$ \\
\hline 13 & $\begin{array}{l}\text { Dosen pembimbing dan pimpinan industri sering } \\
\text { memberikan contoh-contoh jenis usaha yang sesuai dengan } \\
\text { bidang busana }\end{array}$ & 3.72 & 0.81 & $\mathrm{~S}$ \\
\hline $\mathrm{Ke}$ & uruhan & 3.64 & 0.79 & KS \\
\hline
\end{tabular}

3. Dimensi produk

a. Sikap Berwirausaha dan Tahap Pemikiran Berwirausaha Alumni TB FT UNP.

Bahagian ini ditujukan untuk menjawab dimensi produk berkaitan dengan tahap sikap berwirausaha dan tahap pemikiran berwirausaha alumni TB FT UNP. Sikap alumni untuk berwirausaha secara keseluruhan berada pada tahap tinggi dengan skor min 4.00 dan sisihan piawai 0.39. Dari 25 item sikap berwirausaha alumni, 2 item berada pada tahap sederhana, seperti pada tabel 11 
Tabel 11 Skor Min Dan Sisihan Piawai Sikap Berwirausaha Alumni

\begin{tabular}{|c|c|c|c|c|}
\hline \multirow[t]{2}{*}{ No } & \multirow[t]{2}{*}{ Item } & \multicolumn{3}{|c|}{ Sikap berwirausaha } \\
\hline & & Min & S.P & Interpretasi \\
\hline 1 & Akan terus membuka usaha walaupun sering gagal & 3.34 & 0.79 & $\mathrm{~S}$ \\
\hline 2 & Selalu berusaha untuk meningkatkan kualitas kerja & 3.73 & 0.81 & $\mathrm{~T}$ \\
\hline 3 & $\begin{array}{l}\text { Ingin menjadi pengusaha kerana bidang ini dipandang tinggi oleh } \\
\text { masyarakat }\end{array}$ & 4.06 & 0.84 & $\mathrm{~T}$ \\
\hline 4 & $\begin{array}{l}\text { Percaya untuk berhasil dalam bidang wirausaha, perlu menyesuaikan } \\
\text { diri dengan orang banyak }\end{array}$ & 3.55 & 0.94 & $\mathrm{~S}$ \\
\hline 5 & Jarang berdasarkan arahan untuk pekerjaan yang mudah & 3.97 & 0.73 & $\mathrm{~T}$ \\
\hline 6 & $\begin{array}{l}\text { Tidak cepat berputus asa walaupun usaha yang saya jalani kurang } \\
\text { berkembang }\end{array}$ & 3.99 & 0.82 & $\mathrm{~T}$ \\
\hline 7 & Tidak takut gagal dalam menjalankan usaha & 4.05 & 0.70 & $\mathrm{~T}$ \\
\hline 8 & Mempunyai banyak waktu untuk menjalankan usaha & 3.96 & 0.76 & $\mathrm{~T}$ \\
\hline 9 & Selalu tidak puas bila kualitas kerja buruk & 3.97 & 0.75 & $\mathrm{~T}$ \\
\hline 10 & $\begin{array}{l}\text { Sering bekerja keras untuk menjadikan diri yang terbaik dalam suatu } \\
\text { bidang }\end{array}$ & 4.14 & 0.66 & $\mathrm{~T}$ \\
\hline 11 & Gembira apabila mengerjakan tugas dengan cara yang berbeda & 4.14 & 0.60 & $\mathrm{~T}$ \\
\hline 12 & Selalu menjalankan tugas dengan berhati-hati & 4.12 & 0.64 & $\mathrm{~T}$ \\
\hline 13 & Bersedia menerima komentar dan teguran dari pelanggan & 3.69 & 0.84 & $\mathrm{~T}$ \\
\hline 14 & $\begin{array}{l}\text { Merasa tidak nyaman dalam berusaha apabila tidak mendapat } \\
\text { dukungan dari kawan-kawan }\end{array}$ & 3.87 & 0.68 & $\mathrm{~T}$ \\
\hline 15 & $\begin{array}{l}\text { Merasa puas apabila telah bekerja maksimal untuk mencapai sesuatu } \\
\text { yang diinginkan }\end{array}$ & 4.11 & 0.73 & $\mathrm{~T}$ \\
\hline 16 & Menghadapi permasalahan dalam perusahaan dengan tabah & 4.15 & 0.69 & $\mathrm{~T}$ \\
\hline 17 & Selalu menghormati pelanggan & 4.11 & 0.72 & $\mathrm{~T}$ \\
\hline 18 & $\begin{array}{l}\text { Merasa bangga apabila membuat kerja dengan baik dalam setiap } \\
\text { kegiatan }\end{array}$ & 4.11 & 0.64 & $\mathrm{~T}$ \\
\hline 19 & $\begin{array}{l}\text { Merasa sangat puashati dengan hasil kerja apabila berdasarkan } \\
\text { prosedur yang sudah ada }\end{array}$ & 4.07 & 0.56 & $\mathrm{~T}$ \\
\hline 20 & Melaksanakan hal yang penting dan bermakna setiap hari & 4.21 & 0.62 & $\mathrm{~T}$ \\
\hline 21 & Dapat berurusan dengan banyak orang & 4.16 & 0.73 & $\mathrm{~T}$ \\
\hline 22 & $\begin{array}{l}\text { Merasa sangat termotivasi apabila bekerja dengan kawan-kawan yang } \\
\text { berani mencoba sesuatu yang baru }\end{array}$ & 4.14 & 0.70 & $\mathrm{~T}$ \\
\hline 23 & $\begin{array}{l}\text { Bertanggungjawap terhadap tugas-tugas yang terkait dengan usaha } \\
\text { yang dijalankan }\end{array}$ & 3.86 & 0.84 & $\mathrm{~T}$ \\
\hline 24 & Harus ber-etika dalam menjalankan usaha & 4.17 & 0.59 & $\mathrm{~T}$ \\
\hline 25 & $\begin{array}{l}\text { Merasa bangga melihat hasil yang telah dicapai dalam aktivitas- } \\
\text { aktivitas yang dijalankan }\end{array}$ & 4.21 & 0.68 & $\mathrm{~T}$ \\
\hline Kes & aruhan & 4.00 & 0.39 & $\mathrm{~T}$ \\
\hline
\end{tabular}

S.P = Sisihan Piawai $\mathrm{R}=$ Rendah $\mathrm{S}=$ Sederhana $\mathrm{T}$ = Tinggi

b. Tahap Pemikiran Berwirausaha alumni TB FT UNP

Bahagian ini ditujukan untuk menjawab dimensi produk berkaitan dengan tahap pemikiran berwirausaha alumni TB FT UNP. Tahap pemikiran berwirausaha alumni secara keseluruhan berada pada tahap tinggi dengan skor min 3.90 dan sisihan piawai 0.41. Dari 27 item pemikiran berwirausaha, satu item pada tahap sederhana, dapat dilihat pada tabel 12 . 


\section{Tabel 12 Skor Min Dan Sisihan Piawai Tahap Pemikiran Berwirausaha Alumni}

\begin{tabular}{|c|c|c|c|c|}
\hline \multirow[t]{2}{*}{ No } & \multirow[t]{2}{*}{ Item } & \multicolumn{3}{|c|}{ Tahap pemikiran berwirausaha } \\
\hline & & Min & S.P & Interpretasi \\
\hline 1 & $\begin{array}{l}\text { Gembira apabila menemui penyelesaian yang baik untuk permasalahan } \\
\text { yang belum pernah diselesaikan }\end{array}$ & 3.71 & 0.78 & $\mathrm{~T}$ \\
\hline 2 & $\begin{array}{l}\text { Yakin untuk melakukan hal yang mudah yakin pula untuk melakukan hal } \\
\text { yang sulit }\end{array}$ & 3.82 & 0.69 & $\mathrm{~T}$ \\
\hline 3 & $\begin{array}{l}\text { Yakin menghasilkan ide yang terbaik jika melibatkan diri dalam aktifitas } \\
\text { usaha }\end{array}$ & 3.73 & 0.71 & $\mathrm{~T}$ \\
\hline 4 & Peka terhadap perubahan yang terjadi di lingkungan sekitar & 4.21 & 1.91 & $\mathrm{~T}$ \\
\hline 5 & $\begin{array}{l}\text { Dapat menghasilakan ide untuk produk/jasa baru melalui penggabungan } \\
\text { berbagai sumber }\end{array}$ & 3.73 & 0.86 & $\mathrm{~T}$ \\
\hline 6 & $\begin{array}{l}\text { Dapat menghasilkan banyak ide berdasarkan perubahan peraturan } \\
\text { pemerintah }\end{array}$ & 4.04 & 0.70 & $\mathrm{~T}$ \\
\hline 7 & Suka menilai setiap perubahan yang terjadi di lingkungan & 3.99 & 0.71 & $\mathrm{~T}$ \\
\hline 8 & Sedar akan jenis produk yang diminati oleh orang sekitar & 3.92 & 0.70 & $\mathrm{~T}$ \\
\hline 9 & Kecewa jika tidak dapat mencapai suatu tujuan kerja yang ditetapkan & 3.91 & 0.73 & $\mathrm{~T}$ \\
\hline 10 & $\begin{array}{l}\text { Percaya bahwa imbalan yang diterima oleh pengusaha bergantung dengan } \\
\text { resiko dari usaha yang dijalankan }\end{array}$ & 3.93 & 0.73 & $\mathrm{~T}$ \\
\hline 11 & $\begin{array}{l}\text { Dapat mengenalpasti cara-cara baru untuk meningkatkan produk-produk } \\
\text { dipasaran }\end{array}$ & 4.10 & 0.74 & $\mathrm{~T}$ \\
\hline 12 & $\begin{array}{l}\text { Percaya dapat mengatasi masalah yang ada jika mendirikan perusahaan } \\
\text { sendiri }\end{array}$ & 3.97 & 0.65 & $\mathrm{~T}$ \\
\hline 13 & Sering mengaitkan keinginan masyarakat dengan ide usaha & 3.97 & 0.63 & $\mathrm{~T}$ \\
\hline 14 & $\begin{array}{l}\text { Dapat menggabungkan pengetahuan yang dimiliki dengan ide baru dalam } \\
\text { membentuk jenis usaha }\end{array}$ & 3.94 & 0.79 & $\mathrm{~T}$ \\
\hline 15 & Memikirkan ide usaha dengan melihat keperluan masyarakat & 3.97 & 0.68 & $\mathrm{~T}$ \\
\hline 16 & Suka membaca surat kabar untuk mengetahui perkembangan terbaru & 4.04 & 0.63 & $\mathrm{~T}$ \\
\hline 17 & Mampu menghadapi persaingan bisnis & 4.04 & 0.68 & $\mathrm{~T}$ \\
\hline 18 & Seorang pengusaha perlu menjaga hubungan baik dengan rekan bisnisnya & 3.72 & 0.87 & $\mathrm{~T}$ \\
\hline 19 & Selalu berdasarkan perkembangan produk yang diimport kedalam Negari & 3.85 & 0.72 & $\mathrm{~T}$ \\
\hline 20 & Dapat mendeteksi pasar-pasar baru yang dapat ditelusuri untuk produksi/jasa & 3.69 & 0.92 & $\mathrm{~T}$ \\
\hline 21 & $\begin{array}{l}\text { Dapat mengenalpasti sumber-sumber yang ada dan dapat digunakan untuk } \\
\text { menghasilkan produk yang lebih baik dan lebih murah }\end{array}$ & 4.02 & 0.62 & $\mathrm{~T}$ \\
\hline 22 & Yakin dapat menghadapi persaingan sehingga berhasil & 3.88 & 0.71 & $\mathrm{~T}$ \\
\hline 23 & $\begin{array}{l}\text { Sadar akan selera masyarakat terhadap penggunaan teknologi yang } \\
\text { diinginkan pelanggan }\end{array}$ & 3.91 & 0.80 & $\mathrm{~T}$ \\
\hline 24 & Selalu mendapat ide-ide usaha secara tidak sengaja & 3.86 & 0.74 & $\mathrm{~T}$ \\
\hline 25 & Sering berfikir jenis produk yang berpotensi untuk diekspor ke luar Negeri & 3.94 & 0.76 & $\mathrm{~T}$ \\
\hline 26 & Mempunyai ide tentang produk yang diperlukan masyarakat & 3.55 & 1.02 & $\mathrm{~S}$ \\
\hline 27 & Prihatin tentang perubahan keinginan masyarakat dalam memilih busana & 3.87 & 0.75 & $\mathrm{~T}$ \\
\hline Kes & aruhan & 3.90 & 0.41 & $\mathrm{~T}$ \\
\hline
\end{tabular}

\section{KESIMPULAN DAN SARAN}

\section{Kesimpulan}

a. Iklim akademik dan prasarana terhadap pembentukan sikap berwirausaha dan pemikiran berwirausaha alumni secara keseluruhan kurang, dengan skor masing-masing skor min 3,49 dan sisihan piawai 0,83 . skor min 3,47 dan sisihan piawai 0,46 .

b. Kurikulum terhadap pembentukan sikap berwirausaha adalah kurang sesuai dengan skor min 3,33 sisihan piawai 0,92 dan sesuai terhadap pembentukan

pemikiran 
berwirausaha dengan skor min 3,91 sisihan piawai 0,91 .

c. Proses pengajaran dan pembelajaran terhadap pembentukan sikap berwirausaha secara keseluruhan adalah sesuai dengan skor min adalah 3,81 dan sisihan piawai adalah 0,76 , tetapi kurang sesuai terhadap pembentukan pemikiran berwirausaha dengan skor min adalah 3,25 dan sisihan piawai adalah 0,74 .

d. Keterampilan dosen dalam membimbing pelaksanaan latihan industri terhadap pembentukan sikap berwirausaha secara keseluruhan sesuai dengan skor min 3,88 dan sisihan piawai 0,78 dan kurang sesuai terhadap pembentukan pemikiran berwirausaha dengan skor min 3,64 dan sisihan piawai 0,79 .

e. Sikap berwirausaha alumni berada pada tahap tinggi dengan skor min 4.00 dan sisihan piawai 0.39 dan tahap pemikiran berwirausaha alumni juga pada tahap tinggi dengan skor min 3.90 dan sisihan piawai 0.41 .

\section{Saran}

Untuk meningkatkan kesesuaian program diploma tata busana terhadap pembentukan sikap berwirausaha dan pemikiran berwirausaha, disarankan beberapa langkah penting yang perlu dilakukan Program Studi, Jurusan, Fakultas dan Universitas.

Langkah-langkah tersebut adalah :
a. Menyediakan kurikulum yang responsif
b. Menciptakan iklim akademik

yang kondusif

c. Menyediakan prasarana yang mutakhir

d. Pengajaran dan pembelajaran yang inovatif untuk meningkatkan sikap dan pemikiran berwirausaha dengan meningkatkan latihan berwirausaha.

e. Menjalin hubungan dengan pihak industri busana yang betaraf nasional dan international.

f. Melahirkan wirausaha muda yang kreatif dan inovatif yang memiliki sikap dan pemikiran berwirausaha sehingga mampu menciptakan lapangan pekerjaan.

\section{DAFTAR PUSTAKA}

Ashmore, 1990. Entrepreneurship in vocational education. Dlm Kent, C.A (pnyt.) entrepreneurship education current developments, furture direction. Hlm 111-122. New York: Coutum Books.

Badan Pusat Statistik. 2015. Data strategi BPS. Jakarta: Badan Pusat Statistik

Baedhowi, 2008. Strategi peningkatan kualitas dan kompetensi guru direktorat jendral peningkatan mutu pendidikan dan tenaga kependidikan departemen pendidikan nasional, Surabaya

Firdaus Badrun. 2012. Empat masalah ketenaga kerjaan di Indonesia. http://kampus.okezone.com/read I [15 November 2013] 
Fry, F. L. 1993. Entrepreneurship: A Planning Approach. New York: West publishing Company.

Ciputra. 2008. Bagaimana Enterpreneurship Dapat Mengubah Masa Depan Anda dan Masa Depan Bangsa. Jakarta; PT Alex Madia Kumpotindo.

Coulter, M. 2001. Entrepreneurship in Action. New Jersey: Prentice Hall.

Jamil Ahmad. 2002. Pemupukan budaya penyelidikan di kalangan guru sekolah:Satu penilaian .

Tesis Doktor Falsafah:

Universiti Kebangsaan

Malaysia.

Mohd. Majid Konting. 2005. Kaedah penyelidikan pendidikan. Edisi ketujuh. Kuala Lumpur: Dewan Bahasa dan Pustaka.

Ronstadt, R. 1990. The educated entrepreneurs: an era of entrepreneurial education is beginning. Dlm. C. A. Kent (pnyt). Entrepreneurship Education: Current developments, Future

Direction, hlm. 69-88. New York: Quorums Books.

Rudzi Munap. 2003. Penilaian Program Diploma Kesetiausahaan
Eksekutif di Universiti Teknologi Mara: Tesis doktor Falsafah Universiti Kebangsaan Malaysia.

Siswoyo, B.B. 2009. Kewirausahaan dalam Kajian Dunia Akademik. FE UM.

Siswoyo, B.B. et. al. 2009. Penyusunan Strategi Kebijakan Efektivitas Pemanfaatan Corporate Social Responsibility (CSR). Kerjasama Bappeda Provinsi Jawa Timur dan Lembaga Penelitian Universitas Negeri Malang.

Sugiyono, 2006. Metode Penelitian Administrasi, bandung alfabeta.

Stufflebeam, D.L 1971. The Relevance of the CIPP evaluation model for educational accountability. Journal of Research and Development in Education. 5(1): 19-25

Stufflebeam, D.L. \& Shinkfield,A.J. 1988. Sistematic evaluation. Norwell:Kluwer

Stufflebeam, D.L \& Shinkfiel, A.J.2003. Sistematic Evaluation: A self-instruction guide theory and practice. Boston: KluwerNijhoff Publishing 